\title{
THE INNOVATIVE APPROACH TO RELATIONSHIPS WITH CUSTOMERS
}

\author{
Renata Korsakienė \\ Vilnius Gediminas Technical University, \\ Saulètekio al. 11, 10223 Vilnius, Lithuania \\ E-mail:vvfievk@vv.vgtu.lt \\ Received 30 August 2007; accepted 4 October 2008
}

\begin{abstract}
Customer relationship management is a relatively new discipline, which became popular in the last decade. It has to be noted that customer relationship management is oriented toward current customers and allows to attract new customers. Therefore, customer relationship management is related to long-term success in the market. The paper analyses infrastructure, institutional and internal issues which restrict customer relationship management in Lithuanian real estate companies. Presented investigation is based on questioning of real estate companies which encounter the problems of economy slowdown.
\end{abstract}

Keywords: customer relationship management, infrastructure issues, institutional issues, internal issues, national companies, international companies

\section{Introduction}

The intense competition encourages business companies to seek ways, which would allow them to gain and maintain competitive position in the market. Nowadays customers and customer relationship management are seen as the most important assets of business companies. Therefore, customer relationship management is related to long-term success in the market.

Customer relationship management is oriented toward current customers and allows to attract new customers. The company's goals, i.e. higher performance, quality of services, loyalty of customers, etc. motivate the implementation of customer relationship management (Tvaronavičienè, Tvaronavičius 2006; Tvaronavičienè, Degutis 2007). However, companies, striving to implement customer relationship management, encounter various problems. First of all, country's infrastructure and marketing, institutional development issues impact the implementation of customer relationship management. Hence, uneven growth of countries is one of the most important preconditions impacting CRM implementation (Tvaronavičius, Tvaronavičienè
2008; Tvaronavičienè et al. 2008). On the other hand, company's inertia, little understanding of customer relationship management, poor customer relationship management skills, etc. impact the successful adoption of customer relationship management.

The successful adoption of customer relationship management is seen as the relevant issue for Lithuanian companies, which do not have customer relationship management experience and encounter problems raised by hostile business environment. The aim of this paper is to analyse customer relationship management concept in scientific literature, to reveal infrastructure and institutional issues, to analyse internal issues which restrict implementation of customer relationship management. Presented investigation is based on questioning of real estate companies which encounter the problems of economy slowdown.

\section{The definition of CRM concept}

The customer relationships raise opportunities for companies that need to be exploited. De Wulf et al. (2001) point out that a key step of relational approaches to marketing has coincided with the development of 
customer relationship management. Baran et al. (2008) claimed that "as the acronym indicates", the focus of CRM is the customer, particularly existing ones. All scholars almost unanimously agree that Customer Relationship Management (CRM) is a relatively new discipline. Therefore various definitions of CRM were proposed.

According to Paas and Kuijlen (2001) the consensus on the meaning of CRM has not been achieved. The software vendors and business consultants have prompted the vast interest of CRM in the scientific literature. Marketing scholars analyse different aspects of this phenomenon in their works (Plakoyiannaki 2005). Notably, there have been several attempts to propose different forms of CRM. Reinartz et al. (2004) distinguished three different possible levels of CRM: (1) functional, (2) customer facing, and (3) companywide. Other scholars proposed operational, collaborative and analytical CRM (Iriana, Buttle 2006). Operational CRM is seen as "the business processes and technologies that can help improve the efficiency and accuracy of day-to-day customer-facing operations." Therefore it includes sales, marketing, and service automation. Collaborative CRM is seen as "the components and processes that allow a company to interact and collaborate with customers." Therefore it includes voice technologies, Web storefronts, e-mail, conferencing and face-to-face interactions. Analytical CRM "provides analysis of customer data and behavioural patterns to improve business decisions." This includes the underlying data warehouse architecture, customer profiling/segmentation systems, reporting, and analysis (Iriana, Buttle 2006).

Richards and Jones provided two categories of definitions: strategic and operational (Richards and Jones 2008). Scholars state that strategic CRM is seen as the process that identifies customers, creates customer knowledge, builds customer relationships, and shapes customers' perceptions of the firm and its products. On the other hand, operational CRM is related to the processes and technologies that enable better customer relationships.

Baran et al. (2008) have proposed that various CRM definitions can be grouped as:

1) Those that equate CRM with a software package, process, system, or technology;

2) Those that equate CRM with a focus on data storage and analysis;

3) Those that equate CRM with a change in corporate culture from a transaction focus to a relationship or customer-centric focus (The key focus here is on establishing a dialogue with each customer on a one-to-one basis as opposed to generating merely a corporate monologue with large segments of customers.);

4) Those that equate CRM with the important concept of "managing demand";

5) Those that equate CRM with new strategies focused on current customers (identification, selection, acquiring, developing, cross-selling and up-selling, managing, migration, and win back).

Let us reveal each approach in order to highlight the various domains of CRM.

The approach that views CRM as technology, stresses the importance of such activities as: gathering of customer data from all touch points; warehousing of the data, providing easy access to all; and delivering of information based on the data. According to Swift, CRM is seen as an enterprise-wide set of practices enabling to generate customer intelligence by the launch and use of customer databases (Swift 2001). Notably, one group of scholars focus on the technical elements of the CRM process (Plakoyiannaki 2005). Other scholars state, that CRM has to be seen as relationships with customers, which are developed through appropriate communication. This view defines CRM as the relationship-based business model that concentrates on acquisition and retention of customers.

Payne and Frow proposed various CRM definitions that emphasized technology. According to scholars, CRM can be defined from three perspectives: narrowly and tactically as a particular technology solution, wide-ranging technology, and customer-centric (Payne, Frow 2005).

On the other hand, some business consultants indicate the close link between CRM and corporate culture change, i.e. "a different way of doing business, enabled with powerful technology at every customer touch point" (Baran et al. 2008). Hence, some authors analyse CRM as an organizational phenomenon (Srivastava et al. 1999). Various organizational capabilities, i.e. the orientation towards customer relationship and retention, the openness of the firm, the structures and processes to facilitate CRM, impact CRM implementation. Hence, the scholars distinguished such aspects: identification of customers, value creation, retention of current customers and development of customer-firm dialogue (Srivastava et al. 1999).

Reinartz et al. (2004) provided two CRM concepts that emphasize organizational process: customer value and customer retention. For instance, customer value refers to a combination of product (or service) value and relationship value. Payne and Frow (2005) state that logic, "which has evolved from earlier thinking 
on business-to-business and services marketing, that views the customer as a co-creator and co-producer" prevail. On the other hand, product value is seen as trade-off between perceived benefits and sacrifices by a customer regarding supplier's offer.

The approach that considers CRM as an important concept of "managing demand" emphasizes the goals to recognize the best customers, retain them and encourage greater usage of the firm's products or services. Meanwhile, the approach that relates CRM to a business strategy stresses the effective planning and timely implementation. Buttle (2001) stated, that CRM is "the development and maintenance of long-term mutually beneficial relationships with strategically significant customers". The proponents of this approach emphasize the benefit of strategic CRM definition and its consistent usage throughout all organization.

It has to be noted that CRM is founded on four tenets: "customers should be managed as important assets; not all customers are equally desirable; customers vary in their needs, preferences, and buying behaviour, and by a better understanding of their customers, companies can tailor their offerings to maximize overall value" (Baran et al. 2008). Customer relationships are seen as important resources that fulfil four criteria, i.e. are valuable, rare, imperfectly imitable and imperfectly substitutable. Peppers and Rogers claim that if companies don't treat customers as a scarce resource, they focus excessively on the short term (Peppers, Roger 2005). According to scholars, products and services abound, and have become commodity-like. Hence, from the resource-based view customers and customer relationships are seen as the basis for competitive advantage (Gouthier, Schmid 2003). The company, which knows its customers better than rivals, has greater opportunities to increase market share. On the other hand, CRM creates preconditions to invest the right amount in the right customer, to indicate the more profitable customer, and develop retention strategies.

CRM is seen as "management of customer experience" (Baran et al. 2008). In order to do this, companies must understand customers' needs and purchase behaviour, and effectively manage all interactions with each customer.

\section{The advantages of successful CRM implementation}

Baran et al. (2008) claim that "the goal of CRM systems is not merely to establish and maintain a relationship with customers but rather to increase the strength of the relationship from acquaintanceship to partnership". Therefore, the movement from mass marketing to one-to-one marketing, allows involving customer as a partner in product development and marketing. This dominated approach allows concluding that application of CRM creates preconditions to avoid dissatisfied customers (Korsakienè et al. 2008). According to Peppers et al. "even if a competitor offers the same type of customization and interaction, your customer will not be able to enjoy the same level of convenience without taking the time to teach the competitor the lessons your company has already learned" (Peppers et al. 1999).

Scholars identify four basic steps of CRM:

1. Identification of company's customers.

2. Differentiation of company's customers.

3. Interaction with customers.

4. Customization of company's behaviour.

Notably, the successful implementation of these four steps in the company allows to better understand customers and offer more relevant and customized products or services. It is important to note, that even a very modest one-to-one initiative leads to higher results. For instance, increased cross-selling allows tracking very significant financial benefits. On the other hand, the company increases loyalty among customers. The higher levels of customer satisfaction are perceived as "soft" rating that is easily measured and represents the benefits of CRM program. The implementation of CRM requires developing a more efficient organization. Consequently, the higher efficiency allows reducing transaction costs and achieving faster cycle times. Pine et al. claim that the benefit of one-to-one marketing is related to "learning relationship - an ongoing connection that becomes smarter as the two interact with each other, collaborating to meet the customer's needs over time" (Pine et al. 1995). The researches distinguish a very important aspect of learning relationship, i.e. to teach the company more and more about the preferences and needs of customers, which provide the company with an immense competitive advantage. Therefore, the more customers reach the company, the better it becomes at providing exactly what they want exactly how they want it - and the more difficult it will be for a competitor to entice them away (Pine et al. 1995).

The researches state that the advantages of CRM are as follows (Ko et al. 2008):

- increased profits;

- more customer relationships;

- more repurchases;

- accurate customer information collected;

- enhanced customer loyalty;

- improved efficiency of customer management;

- effect of word of mouth; 
- reduced cost of new customer acquisition;

- greater ease in developing new products;

- increased sales by additional purchases;

- reduced cost of direct marketing;

- increased brand loyalty;

- increased customer lifetime value.

On the other hand, King and Burgess distinguish tangible and intangible benefits of CRM (King, Burgess 2008).

According to the survey conducted by Bain \& Company in 2003, firms began to report increased satisfaction with their CRM investments. For instance, $82 \%$ of surveyed executives said they planned to adopt CRM in their companies. Meanwhile, only $35 \%$ of executives employed CRM in their companies in 2000 (Rigby, Ledingham 2004).

Notably, the positive effect of customer retention is related to company's profit. For instance, Reichheld and Sasser (1990) indicate that a 5 percent increase in customer retention yielded improved profitability in net present value from 20 to 85 percent across a wide range of businesses. The research, carried out by McKinsey has shown that repeat customers generate over twice as much gross income as new customers. According to Winer (2001) the improvement in technology and innovation on CRM-related products have made it much easier to deliver on the promise of greater profitability from reduced customer "churn".

To conclude, the majority of scholars assert that CRM increases value for both customers and companies. Gamble et al. (2006) state that "CRM has provided the highest positive impact in the areas of improving the customer experience and in helping companies to retain and expand their customer base".

\section{Issues of CRM implementation}

According to Sharma and Iyer (2006), country has the effect on CRM strategy outcomes. Scholars classify countries using two dimensions - the country's infrastructure development and the country's marketing institutional development. Scholars point out that not all countries have ideal conditions for CRM. In order to justify this statement an example of customer data collection and dissemination is used.

Notably, in countries, characterized by the developed infrastructure and competitive marketing institutions, the tendencies to collect additional customer information prevail. Nevertheless, scholars point out that „the mere collection of additional customer information may not provide the firm with a competitive advantage" (Sharma, Iyer 2006).
In countries, characterized by the developed infrastructure and restricted marketing development, the possibility to collect and disseminate customer data is restricted. A lack of third-party vendors on account of legal or cultural reasons is seen as the main issue restricting the collection of data. Hence, the implementation of CRM strategy becomes difficult.

Countries characterized by a low level of infrastructure development and developed marketing institutions, have the ability to implement CRM strategies. However, the possibility to acquire customer data from public or third-party entities is seen as an issue. Anyway, the advantage is that all the data collected by the firm are not available elsewhere and CRM database is seen as a competitive advantage of the firm.

Scholars point out that in the last category of countries, characterized by both the low infrastructure development and the low marketing institutional development ,there are periods of shortages and surpluses that reduce the need for CRM strategy" (Sharma, Iyer 2006).

Countries that are characterized by well-developed infrastructure relevant for marketing have good logistics systems and well-developed systems in place for capturing customer information. Notably, countries that do not have such systems for capturing customer information rely on the individual retailers to provide them with customer information. Scholars point out that countries with well-developed infrastructure but low marketing institutional development do not collect such data due to privacy laws and concerns.

Sharma and Iyer (2006) state that "the data integration process requires that data from different sources have to be integrated into a unified and accessible warehouse". Countries with well-developed infrastructure and developed marketing institutions are networkready. Hence, they integrate data from various sources and integrate the data across firms in a vertical relationship. In the countries with less developed marketing and communication infrastructure data are not codified uniformly. Therefore the integration process is seen as more complicated and costly. Furthermore, the cooperation within a value chain may not exist.

Notably, countries with well-developed infrastructure and marketing institutions apply analytical techniques which are a critical component of CRM strategy. According to Sharma and Iyer (2006) in markets that are not competitive or in economies that are primarily supply-led, the importance and utility of CRM programs may not be acknowledged.

According to Baran et al. (2008) research carried out in the field of CRM show that real barriers to effective 
CRM implementation appear to be "corporate culture, employee attitudes, organizational structure, and the lack of strategic plan for the CRM implementation". Hence, the main factors impacting CRM implementation reside within "software" side of the business (skills, strategy, structure and style). Blery and Michalakopoulos (2006) claim that CRM should be placed at the heart of the organization and a holistic approach should be adopted because CRM reaches into many parts of the business. Scholars state that CRM involves business process change to align with the system. For instance, the research carried out by Forsyth took a sample of about 700 companies, with regard to the causes of failure to reach the CRM benefits (Mendoza et al. 2007). The main causes of failure were:

- Organizational change (29\%).

- Company policies/inertia (22\%).

- Little understanding of CRM (20\%).

- Poor CRM skills (6\%).

On the other hand, technology adoption is seen as an issue. Due to a lack of the resources to develop CRM software, many firms have to outsource a significant proportion of their CRM solution (Bull 2003). Moreover, it is agreed that in many cases external consultants should be used to acquire knowledge of CRM. The need of external consultants is raised by basic understanding of CRM and limited time to research CRM. Blery and Michalakopoulos (2006) distinguish such factors that impact implementation of CRM:

1) process fit, i.e. the CRM system must be designed around an elaborate understanding of a CRM process so as to leverage the marketing and sales effort;

2) customer information quality, i.e. making effective use of customer information resources;

3) system support because only if the system has been implemented and adopted successfully, a firm is able to reap its benefits.
Chen and Popovich (2003) state that in the implementation of CRM a series of aspects are involved:

1) the Processes through which the customer relates to the organization;

2) the Human factor (people);

3) the Technology.

The conclusion we can draw is, that both the external and internal factors impact the successful CRM implementation.

\section{Survey of real estate companies' attitude towards CRM implementation}

A survey was conducted in order to reveal the approach of real estate companies regarding CRM implementation. This survey was based on responses to a questionnaire that embraced infrastructure, institutional and internal issues of CRM implementation. Another goal of the survey was to detect differences between attitudes of national and international companies.

Companies were selected randomly. The questionnaires were delivered by e-mail and mail. A survey was conducted in March-May of 2008. 90 respondents participated in the survey.

Structure of respondents according to the capital is as follows: $73 \%$ national and $27 \%$ international companies. The majority of respondents $(58 \%)$ represent small companies where the number of employees reaches 49 people. The division according to the activity of real estate companies is as follows: selling of flats and dwelling-houses (87\%), selling of commercial premises (73\%) and selling of plots (58\%). 42\% of respondents who filled in questionnaires occupy topmanaging positions in their companies, $18 \%$ of them are owners. The work experience of the majority of respondents $(71 \%)$ in this business sector is less than three years.

The associations of respondents raised by CRM

\begin{tabular}{lccc}
\hline \multicolumn{1}{c}{ The associations raised by CRM } & $\begin{array}{c}\text { Responses } \\
\text { of all } \\
\text { companies, } \%\end{array}$ & $\begin{array}{c}\text { Responses } \\
\text { of national } \\
\text { companies, } \%\end{array}$ & $\begin{array}{c}\text { Responses } \\
\text { of international } \\
\text { companies, } \%\end{array}$ \\
\hline Strategy focused on current customers & 91 & 67 & 67 \\
\hline Data storage and analysis & 40 & 42 & 33 \\
\hline Demand management & 22 & 24 & 17 \\
\hline $\begin{array}{l}\text { A change in corporate culture from a transaction focus } \\
\text { to a relationship or customer-centric focus }\end{array}$ & 18 & 21 & 8 \\
\hline $\begin{array}{l}\text { Software package, process, system, or technology } \\
\text { adopted in organization }\end{array}$ & 11 & 12 & 8 \\
\hline
\end{tabular}


The respondents were asked to indicate associations raised by CRM. The obtained data allow concluding that CRM is associated with strategy focused on current customers $(91 \%)$, data storage and analysis (40\%) and demand management (22\%) (Table). The responses of national and international companies did not differ significantly.

\section{Institutional issues}

The respondents were asked to indicate institutional issues restricting CRM implementation. The obtained data allow concluding that CRM implementation is restricted due to poor adaptation of data into usable form (33\% of all respondents), lack of direct contact with customers (31\% of all respondents), prevalence of "Marketing Mindset" (31\% of all respondents) and low focus on competitive advantage ( $29 \%$ of all respondents) (Fig. 1).

The responses of national and international companies were compared. International companies indicate that CRM implementation is restricted due to poor adaptation of data into usable form ( $42 \%$ of all international respondents), lack of direct contact with customers ( $25 \%$ of all international respondents) and prevalence of "Marketing Mindset" ( $25 \%$ of all international respondents). Meanwhile, national companies indicate that CRM implementation is restricted due to a lack of direct contact with customers (33\% of all national respondents), prevalence of "Marketing Mindset" (33\% of all national respondents) and low focus on competitive advantage (33\% of all national respondents). The conclusion we can draw is that the problems occur at the first stage of CRM process. All companies indicate "the lack of direct contact with customers" which oc-

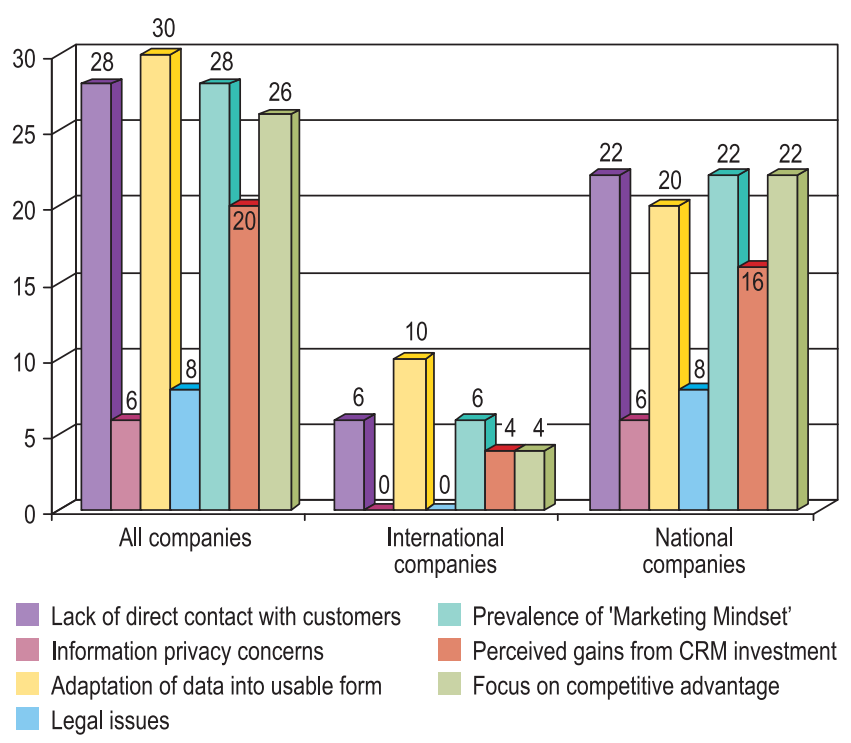

Fig. 1. Institutional issues restricting CRM implementation curs due to intermediation in this business sector. One of the reasons might be related to the enormous rise of speculation in this sector during the real estate market boom. The above mentioned data integration process requires that "data from different sources have to be integrated into a unified and accessible warehouse" (Sharma and Iyer 2006). However, international companies indicate that adaptation of data into usable form is restricted. Therefore, the communication infrastructure in the country is considered as rather poor. The respondents indicate the prevalence of "Marketing Mindset" or according to Sharma and Iyer (2006) "the managerial orientation towards gaining customer-based competitive advantages" which restricts the analysis of acquired data. Lastly, the respondents indicate that implementation of CRM programmes is restricted due to poor focus on the competitive advantage which might be gained from building loyal relationships with customers.

\section{Infrastructure issues}

The responses of respondents to the question about infrastructure issues restricting CRM implementation let us reveal that companies experience a lack of human capital capable to apply data for strategic use ( $40 \%$ of all respondents) and lack of cooperation with customers (38\% of all respondents) (Fig. 2). The obtained data allow to compare the responses of international and national respondents. International respondents indicate that CRM implementation is restricted due to a lack of human capital ( $42 \%$ of all international respondents), lack of cooperation with customers ( $25 \%$ of all international respondents) and availability of data capture mechanisms ( $25 \%$ of all international re-

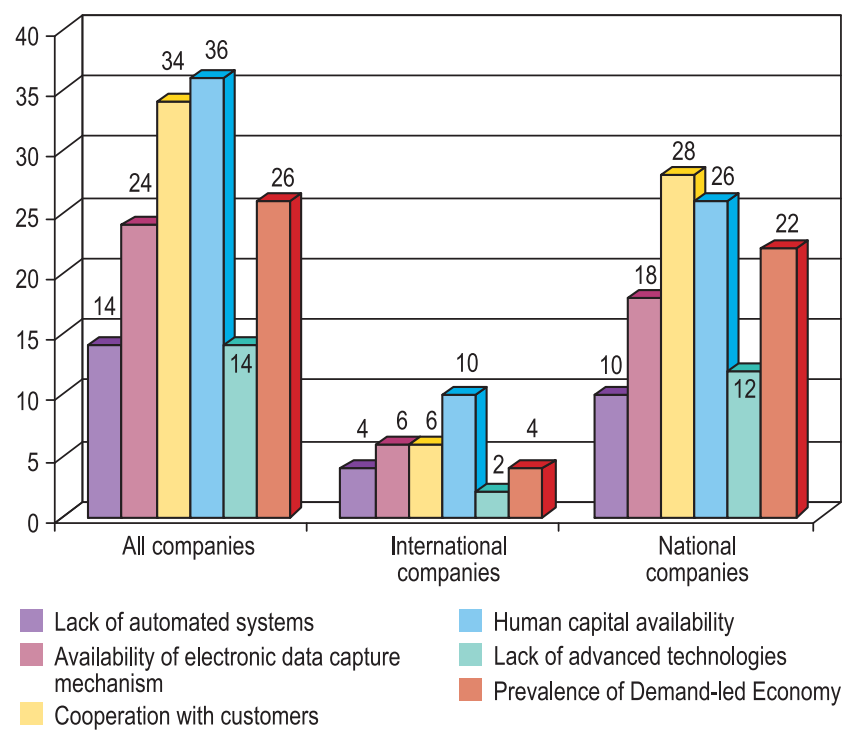

Fig. 2. Infrastructure issues restricting CRM implementation 
spondents). National respondents indicate that CRM implementation is restricted due to poor cooperation with customers ( $42 \%$ of all national respondents), lack of human capital (39\% of all national respondents) and prevalence of demand-led economy (33\% of all national respondents).

The conclusion we can draw is that problems occur in the data integration process due to a lack of cooperation within the value chain. Furthermore, the companies indicate lack of human capital which is related to analytical marketing skills.

\section{Internal issues}

The responses of respondents to the question about internal issues restricting CRM implementation let us reveal that companies do not have sufficient budget of CRM ( $82 \%$ of all respondents), experience a high turnover of employees (74\% of all respondents) and do not have efficient processes of marketing, selling and service providing (71\% of all respondents) (Fig. 3).

International respondents indicate that CRM implementation is restricted due to such internal factors as insufficient budget of CRM (67\%), a high turnover of employees (58\%) and insufficient processes of marketing, selling and service providing (58\%). Meanwhile, national companies indicate such issues as: insufficient budget of CRM (76\%), a high turnover of employees $(70 \%)$, insufficient processes of marketing, selling and service providing $(67 \%)$ and a lack of motivation to accept the risks (67\%). The conclusion we can draw is, that the main problems occur in the areas of human resource management, finance management and marketing.

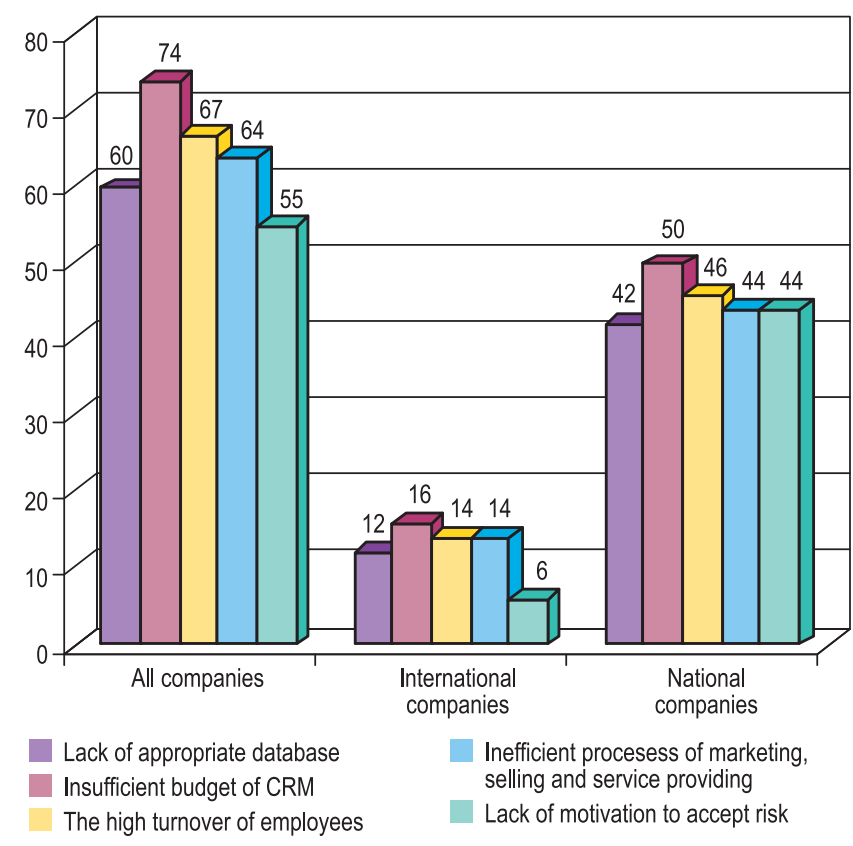

Fig. 3. Internal issues restricting CRM implementation

\section{Conclusions}

CRM is to be perceived as significant approach impacting the success of business company in the long run. However, the successful implementation of CRM is seen as one of the challenging tasks. In the paper analysis of CRM implementation issues in Lithuanian real estate companies has been presented, with an emphasis on institutional, infrastructure and internal issues.

The results of the survey allow to conclude that the concept of CRM is considered as "strategy focused on current customers". Both international and national companies agreed upon this statement. Hence, Lithuanian real estate companies understand the importance of CRM in their activity and the impact on the performance.

The real estate indicated infrastructure and institutional issues which were formulated according to Sharma and Iyer (2006) proposition.

The implementation of CRM by real estate companies is restricted due to a poor possibility to adapt acquired data about customers into a usable form, lack of direct contact with customers and prevalence of "Marketing Mindset" and low focus on competitive advantage. The implementation of CRM is restricted by such infrastructure issues as: lack of human capital capable to apply data for strategic use and lack of cooperation with customers in the value chain. Hence, Lithuanian real estate companies encounter problems raised by less developed marketing and communication infrastructure in the country.

On the other hand, both international and national companies encounter such internal problems as insufficient budget of CRM, a high turnover of employees and insufficient processes of marketing, selling and service providing. Hence, the distinguished problems require changing of all internal processes, putting emphasis on human resources management practice and marketing.

\section{References}

Baran, R. J.; Galka, R. J.; Stunk, D. P. 2008. Principles of customer relationship management. Thomson South-Western.

Blery, E.; Michalakopoulos, M. 2006. Customer relationship management: A case study of a Greek bank, Journal of Financial Services Marketing 11(2): 116-124.

Bull, C. 2003. Strategic issues in customer relationship management (CRM) implementation, Business Process Management Journal 9(5): 592-602.

Buttle, F. A. 2001. The CRM Value Chain, Marketing Business (February): 52-55. 
Chen I.; Popovich, K. 2003. Understanding customer relationship management (CRM). People, process, and technology, Business Process Management Journal 9(5): 672-688.

De Wulf, K.; Odekerken-Schroder, G.; Iacobucci, D. 2001. Investments in Consumer Relationships: A Cross-Country and Cross-Industry Exploration, Journal of Marketing 65(4): 33-50.

Gamble, P. R.; Stone, M.; Woodcock, N.; Foss, B. 2006. Up Close \&Personal? Customer Relationship Marketing @ Work. Kogan Page London.

Gouthier, M.; Schmid, S. 2003. Customers and customer relationships in service firms: The Perspective of the resourcebased view, Marketing Theory 3(1): 119-143.

Iriana, R.; Buttle, F. 2006. Strategic, operational, and analytical customer relationship management: Attributes and Measures, Journal of Relationship Marketing 5(4): 23-42.

King, S. F.; Burgess, T. F. 2008. Understanding success and failure in customer relationship management, Industrial Marketing Management 37(4): 421-431.

Ko Eunju; Kim Sook Hyun; Kim Myungsoo; Woo Jiyoung. 2008. Organisational characteristics and the CRM adoption process, Journal of Business Research 61: 65-74.

Korsakienè, R.; Tvaronavičius, V.; Mačiulis, A. 2008. Ryšių su klientais valdymas nekilnojamojo turto sektoriaus imonėse: privalumų ir ribojančių veiksnių tyrimas [Customer Relationship Management in Real Estate Companies: The Research of Advantages and Restrictive Factors], Verslas: teorija ir praktika [Business: Theory and Practice] 9(3): 190-198.

Mendoza, L. E.; Marius, A.; Pérez, M.; Grimán, A. C. 2007. Critical success factors for a customer relationship management strategy, Information and Software Technology 49: 913-945.

Paas, L.; Kuijlen, T. 2001. Towards a general definition of customer relationship management, Journal of Database Marketing 9(1): 51-60.

Payne, A.; Frow, P. 2005. A strategic framework for customer relationship management, Journal of Marketing 69(4): 167-176.

Peppers, D.; Rogers, M. 2005. Return on Customer. Creating Maximum Value from Your Scarcest Resource. Marshall Cavendish Business.

Peppers, D.; Rogers, M.; Dorf, B. 1999. Is your company ready for one-to-one marketing? Harvard Business Review 77(1): 151-160.
Pine, B. J.; Peppers, D.; Rogers, M. 1995. Do you want to keep your customers forever? Harvard Business Review 73(2): 103-114.

Plakoyiannaki, E. 2005. How do organisational members perceive CRM? Evidence from a U.K. Service firm, Journal of Marketing Management 21: 363-392.

Reichheld, F. F.; Sasser, Jr., W. E. 1990. Zero defections: Quality comes to services, Harvard Business Review 68(5): 105-111.

Reinartz, W. J.; Krafft, M.; Hoyer, W. D. 2004. The customer relationship management process: Its measurement and impact on performance, Journal of Marketing Research 41(3): 293-305.

Richards, K. A.; Jones, E. 2008. Customer relationship management: Finding value drivers, Industrial Marketing Management 37: 120-130.

Rigby, D. K.; Ledingham, D. 2004. CRM Done right, Harvard Business Review 82(11): 118-129.

Sharma, A.; Iyer, G. R. 2006. Country effects on CRM success, Journal of Relationship Marketing 5(4): 63-78.

Srivastava, R. K.; Shrevani, T. A.; Fahey, L. 1999. Marketing, business processes, and shareholder value: An organizationally embedded view of marketing activities and the discipline of marketing, Journal of Marketing 63: 168-179.

Swift, R. S. 2001. Accelerating customer relationships: using CRM and relationship technologies. Upper Saddle River, NJ: Prentice Hal.

Tvaronavičienè, M.; Degutis, M. 2007. If approach to innovations differs in locally and foreign-owned firms: case of Lithuania, Journal of Business Economics and Management 8(3): 195-203.

Tvaronavičienė, M.; Tvaronavičius, V. 2006. Kai kurie Lietuvos ekonominio augimo aspektai [Some aspects of Lithuanian economic growth], Verslas: teorija ir praktika [Business: Theory and Practice] 7(5): 232-236.

Tvaronavičius, V.; Tvaronavičienè, M. 2008. Role of fixed investments in economic growth of country: Lithuania in European context, Journal of Business Economics and Management (9)1: 57-65.

Tvaronavičienė, M.; Ginevičius, R.; Grybaitè, V. 2008. Baltijos šalių išsivystymo palyginimas: praktiniai kompleksinio požiūrio taikymo aspektai [Comparisons of Baltic countries “ development: practical aspects of complex approach], Verslas: teorija ir praktika [Business: Theory and Practice] 9(1): $51-65$

Winer, R. S. 2001. A framework for customer relationship management, California Management Review 43(4): 89-105. 